\title{
高信頼ファインピッチBGAの構造設計
}

\author{
矢口昭弘*, 田中 直敬*, 安生 一郎 ${ }^{* *}$
}

\section{Structural Design of Highly Reliable Fine-Pitch BGA}

Akihiro YAGUCHI*, Naotaka TANAKA* and Ichiro ANJOH**

\footnotetext{
$*$ 株式会社日立製作所機械研究所（３00-0013＼cjkstart茨城県土浦市神立町502）

**株式会社日立製作所半導体グループ（テ187-0022＼cjkstart東京都小平市上水本町5-20-1）

* Mechanical Engineering Research Laboratory, Hitachi, Ltd. (502 Kandatsu-machi, Tsuchiura-shi, Ibaraki 300-0013)

**Semiconductor and Integrated Circuits Group, Hitachi, Ltd. (5-20-1 Jyosuihoncho, Kodaira-shi, Tokyo 187-0022)
}

概要 応力緩和層を内包した高信頼ファインピッチBGAタイプCSPの開発を目的として, 封止樹脂部のリードとはんだ接 続部の信頼性向上を両立させるパッケージ構造仕様を弾塑性有限要素法解析によって検討した。樹脂封止部のリードに発生す るひずみは, リード根元部分の幅広化, S字型断面形状の形成, および応力緩和層の高弾性化と厚さの適正化によって低減で きる。応力緩和層の高弾性化は，はんだ接続部の信頼性を低下させる要因となるが, 弾性率の最適化によってリードとはんだ 接続部双方の信頼性を確保することができる。以上の結果に基づいて耐温度サイクル性に優れたCSPを開発した。

\begin{abstract}
We used an elasto-plastic finite element method to analyze the fatigue life of solder bump joints and inner leads and improve the reliability of fine-pitch the BGA-type chip-size packages under temperature cycling. We mainly studied the effect of the Young's modulus of the elastomer and the encapsulate resin on the plastic strain of the inner lead and solder bump joint. To reduce the strain of the inner lead, the Young's modulus of the elastomer and width of the inner lead should be increased is important. Since it is also important to reduce the Young's modulus of the elastomer to improve the fatigue life of the solder joints, there is an optimum range for the Young's modulus. By considering the reliability of both the inner lead and the solder joint, a highly reliable fine-pitch the BGA has been developed by optimizing the inner lead shape and the Young's modulus of the elastomer.
\end{abstract}

Key Words: Chip Size Package, Elastomer, Inner Lead, Solder Bump Joints, Reliability, Fatigue Life, FEM

\section{1. 緒 言}

携帯情報機器の小型・軽量化と多機能化により，これに 搭載するLSIパッケージにも小型, 薄形化に加えて多ピン 化, 高速化への対応が要求されており, 従来パッケージと 同等以上の信頼性確保も不可欠となっている。そのため, 信頼性の向上と小型化を両立させた種々のCSP(Chip Size Package)が開発され ${ }^{1)-51}$ ，実用化が図られている。

開発されたCSPの大部分は，パッケージの小型化を戝る ために実装基板との接続に微細なはんだバンプを使用した BGA(Ball Grid Array)構造が採用されており，はんだバン プは, チップの面内直下に配置されている。そのため, 実 装状態で温度サイクルなどの温度変化が加わると, はんだ 接続部にはパッケージと実装基板の線膨張係数差に起因し た熱ひずみが発生する。パッケージ構造や実装構造が適正 でない場合には，ひずみが増加してはんだ接続部に疲労破 壊が発生し, 信頼性を著しく低下させる要因となる。した がって, CSPでは, はんだ接続部の信頼性確保が重要課題
となっている。

はんだ接続部の信頼性を向上させるパッケージ構造のひ とつとして, パッケージ内部に応力緩和層を内包し, 箔状 の内部リードでチップとバンプを接続するCSP構造が, 米 国テセラ社（Tessera, Inc.）より提案され, 開発が進めら れている ${ }^{1111}$ 。低弾性のエラストマー樹脂からなる応力緩 和層がチップとはんだバンプとの間に設けられており，こ の応力緩和層の変形によってはんだ接続部に発生するひず みを低減することができる。しかし，応力緩和層を極端に 低弾性化すると, 応力緩和層自体の変形増加に伴って内部 リードに発生するひずみが増加し，信頼性が低下する場合

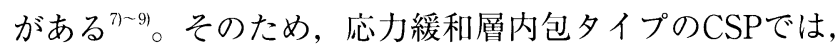
はんだ接続部と内部リード両者の信頼性をバランス良く確 保した構造設計が重要となっている。

そこで, 応力緩和層を内包した高信頼ファインピッチ BGA夕イプCSPの開発を目的として, 内部リードに発生 するひずみに及ぼす構造因子の影響を有限要素法解析によ って検討し，温度サイクルに対する内部リードの信頼性を 


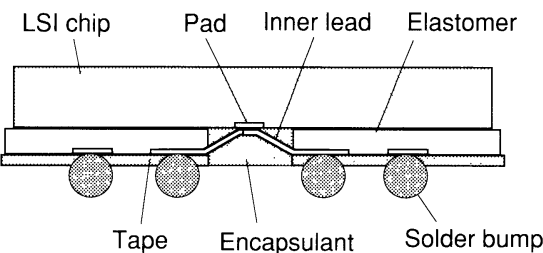

Fig.1 Structure of center pad type CSP

向上するパッケージ構造仕様を解明した。また，はんだ接 続部とリードに発生するひずみとエラストマー弾性率の相 関性を検討し，両者の信頼性を両立できる適正なエラスト マー弾性率を明らかにした212。

\section{2. 応力緩和層内包タイプBGA構造と課題}

応力緩和層を内包したファインピッチBGAタイプの CSPは, Fig. 1 に示すようにチップとはんだバンプとの間 に低弾性のエラストマー樹脂が応力緩和層として設けられ ているのが特徵である。インタポーザには，箔状のリード が形成されたポリイミドテープを用いており，リード形成 面がエラストマー樹脂と接している。リードとチップ表面 のパッドが接合される部分は封止樹脂で覆われている。リ 一ド材料にはコスト低減のためCuが用いられている。エ ラストマー樹脂や封止樹脂の縦弾性率（ヤング率）は，エ ラストマー自身の変形や封止樹脂で覆われる内部リードの 変形を容易にするため，数十 $\mathrm{MPa}$ 程度になっている。

上記構造のCSPでは, チップと実装基板の線膨張係数差 によってはんだ接続部に発生するひずみを，エラストマー 樹脂の変形によって吸収することではんだ接続部の高寿命 化を図っている。しかし，エラストマー樹脂の材質やリー ド構造が適切でない場合には，エラストマー樹脂の変形に より樹脂封止部のリードにも大きな変形（ひずみ）が発生 し，リードの寿命が低下する場合があるが?そここで，リ 一ドのひずみを支配する構造因子を検討し，信頼性を向上 させるリードおよびパッケージ構造仕様を明らかにした。 次いで，リードとはんだ接続部双方の信頼性を両立させる ためのエラストマー材質を明らかにした22。

本研究は，はんだ接続部とリードの温度サイクル試験に 対する寿命を解析の対象としており，発生するひずみも比 較的大きくなるため, 低サイクル疲労に対する強度評価が 必要となる。そこで, リードの寿命評価も, 従来はんだ接 続部の評価に用いている相当塑性ひずみ範囲 ${ }^{13.14}$ に基づい て評価した。

\section{3. 内部リードのひずみに及ぼす構造因子の影響}

\section{1 解析方法}

樹脂封止部のリードには，エラストマー樹脂とリードを 覆う封止樹脂の変形に起因してひずみが発生する。しかし， 封止樹脂をエラストマー樹脂と同様に低弾性の材料で構成 した場合，リードは封止樹脂の内部で比較的自由に変形で きるため，封止樹脂自体の変形がリードのひずみに与える
影響は小さいと考えられる。そこで，まずリード形状やエ ラストマー材質がリードひずみに及ぼす影響を沉用の弾塑 性構造解析ソフトであるADINAを使用して検討した。

解析は以下に述べる 2 段階で行った。まず，Fig. 2 に示 すようにリードを含めた 3 次元のパッケージ全体を粗い要 素分割モデルで作成し，はんだバンプによって実装基板に 接合した状態におけるリード両端（テープ根元部分とチッ プとの接合部分）に発生する変形量を熱応力解析によって 算出した。実際の解析モデルでは，リードは封止樹脂で覆 われているが，Fig. 2ではリードが見えるように封止樹脂 を取り除いた状態を示している。また，対称性を考慮して パッケージの1/4部分をモデル化して抒り，リードを表示 させるためFig. 1 とは上下を逆にして示してある。パッケ ージサイズは $5.9(\mathrm{x}) \times 10.7(\mathrm{y}) \mathrm{mm}$, チップ厚は $0.28 \mathrm{~mm}$ であ り，はんだバンプ数は40である。パッケージ中央部に $\mathrm{y}$ 方 向に沿ってパッドを設けた構造とし，この部分に樹脂封止 部とパッケージのx方向に延びたリードを設けている。解 析した温度範囲は, $-55^{\circ} \mathrm{C} \sim 125^{\circ} \mathrm{C}$ の温度サイクル試験を 想定し， $180^{\circ} \mathrm{C}$ とした。次いで, 求めたリード両端の変形 量をFig. 3 のようなリード単体の 3 次元詳細モデルに強制 変位として与え，樹脂封止部のリードに発生する相当塑性 ひずみ範囲を求めた。解析に使用した各部材の材料定数を Table 1 に示す。エラストマー樹脂および封止樹脂にはシ リコーン系樹脂を想定した材料物性を用いた。

\section{2 リード形状の影響}

Fig. 4 に樹脂封止部のリード幅を $34 \mu \mathrm{m}$ 一定とした場合 の相当塑性ひずみ分布の解析結果を示す。本解析では, リ ードの長手方向の断面形状はFig. 3 のようなテープ根元部 分に根元部から約 $130 \mu \mathrm{m}$ 離れた位置まで水平部を有するS 字形状とし, エラストマー厚さは $160 \mu \mathrm{m}$ とした。封止樹脂 部のリードでは，テープ根元部，屈曲部およびチップ接合 部などの複数個所にひずみが集中して発生することが知ら れているが8，Fig.4のリード幅一定の形状では，テープ 根元部分（Tape edge）に特に大きなひずみが集中して発

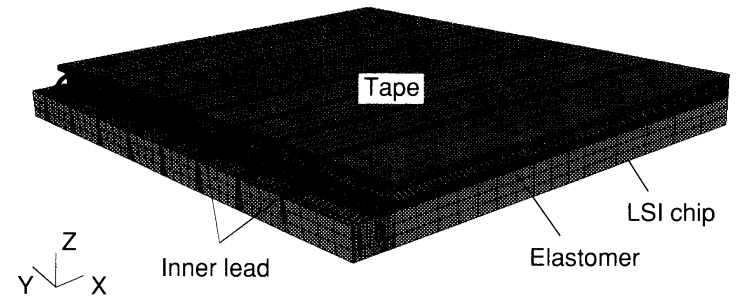

Fig.2 FEM model for estimating strain in inner leads

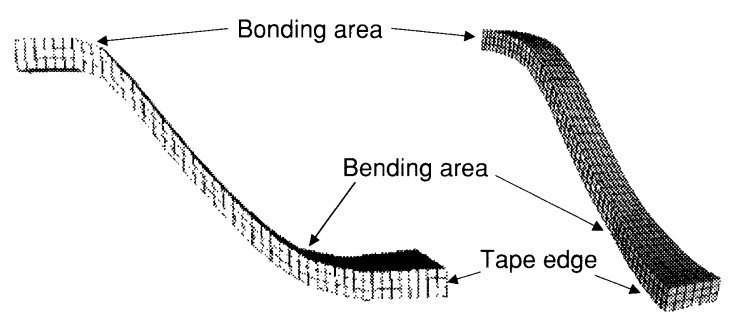

Fig.3 Finite element mesh for an inner lead 
Table 1. Material properties

\begin{tabular}{|c|c|c|c|c|c|c|}
\hline Component & Material & $\begin{array}{l}\text { Young's } \\
\text { Modulus } \\
\text { (MPa) }\end{array}$ & $\begin{array}{c}\text { Poisson's } \\
\text { Ratio }\end{array}$ & $\begin{array}{l}\text { Coefficient } \\
\text { of Thermal } \\
\text { Expansion } \\
\left(\operatorname{ppm} /{ }^{\circ} \mathrm{C}\right)\end{array}$ & $\begin{array}{c}\text { Yield } \\
\text { Stress } \\
(\mathrm{GPa})\end{array}$ & $\begin{array}{c}\text { Strain } \\
\text { Hardening } \\
\text { Exponent } \\
(\mathrm{GPa})\end{array}$ \\
\hline Chip & $\mathrm{Si}$ & 190000 & 0.07 & 3 & & \\
\hline Lead & $\mathrm{Cu}$ & 110000 & 0.35 & 17 & 3700 & 3590 \\
\hline Tape & Polyimide & 9000 & 0.45 & 9 & & \\
\hline Elastomer & Silicone & 10 & 0.45 & 250 & & \\
\hline Encapsulant & Silicone & 10 & 0.45 & 250 & & \\
\hline Solder Bump & $\mathrm{Sn} 37-\mathrm{Pb} 64$ & 29400 & 0.3 & 26.3 & 23.2 & 508 \\
\hline Printed Wiring Board & FR-4 & 17000 & 0.16 & 15 & & \\
\hline
\end{tabular}

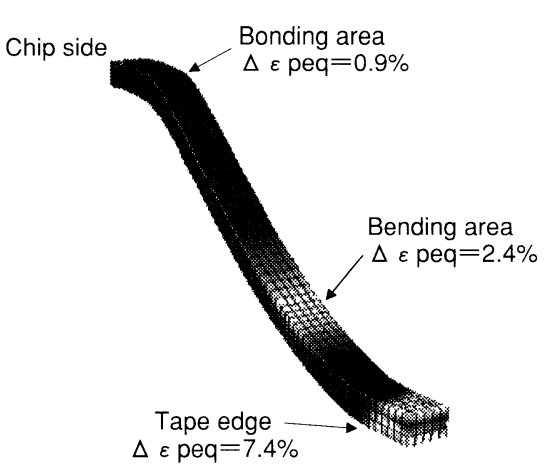

Fig.4 Distribution of equivalent plastic strain in an inner lead with constant width $(34 \mu \mathrm{m})$

生している。本リード構造では，エラストマーの厚さ方向 とパッケージ中心方向への変形によって，テープ根元では ねじれ変形が生じるため，この部分にひずみが集中する。 したがって，リードに発生するひずみを低減するには，1 個所への極端なひずみ集中を避けるひずみ分散構造の採用 が必要となる。

テープ根元部分のひずみ低減のため，テープ根元部分の リード幅のみを広くした場合のリード各部のひずみ変化を 解析した。リードの長手方向の断面形状はFig. 4 と同じと し，テープ根元部の幅を $34 \mu \mathrm{m} \sim 100 \mu \mathrm{m}$ の範囲で変え，根 元部から $130 \mu \mathrm{m}$ 離れた位置まではリード幅が連続的に変化 するテーパ部を形成し，この部分からチップ接合部までは リード幅 $34 \mu \mathrm{m}$ のまとした。解析結果をまとめてFig. 5

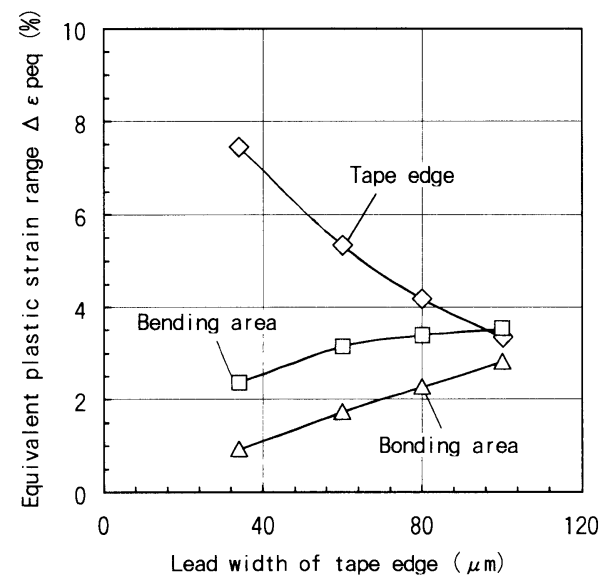

Fig.5 Relationship between equivalent plastic strain range and lead width of tape edge
に示す。テープ根元部の幅を広くすることで，テープ根元 部 (Tape edge）のひずみは単調に減少するが，他の部分 に発生するひずみは増加し, 根元部の幅が約 $100 \mu \mathrm{m}$ の場合, 各部に発生するひずみがほぼ一様となる。このように，テ ープ根元部を幅広にすることによって，リードに発生する ひずみを分散でき，最大ひずみを低減できることが明らか になった。

Fig. 6 はリード長手方向の断面形状が異なる 2 種類のリ ードについて，リード各部に発生する相当塑性ひずみを比 較したものである。テープ根元部の幅は $80 \mu \mathrm{m}$ とし, 根元 部から $130 \mu \mathrm{m}$ 離れた位置まで幅方向のテーパ部を形成し た。解析したモデルのエラストマー厚は $100 \mu \mathrm{m}$ である。 Fig. 6 (a)は，テープ根元近傍のテーパ形成部分を水平とし てS字型とした形状，(b)はテープ根元部からチップ接合部 までストレートの形状である。眓中の各值はひずみを示し ており，解析した範囲で得られた最大相当塑性ひずみ範囲 （Fig. 6 (b)のチップ接合部で発生）に対する相対值で表し ている。Fig. 6 (a)の形状では, 各部のひずみがほぼ一様で あるのに対し，(b)のストレート形状ではチップ接合部に 約 2 倍のひずみが集中して発生している。このようにリー ド自体の変形吸収を可能とする形状にすることで, リード

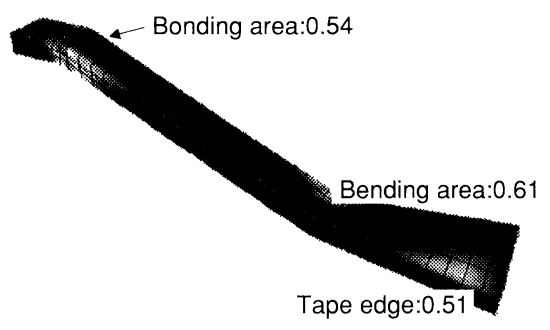

(a) Curved shape

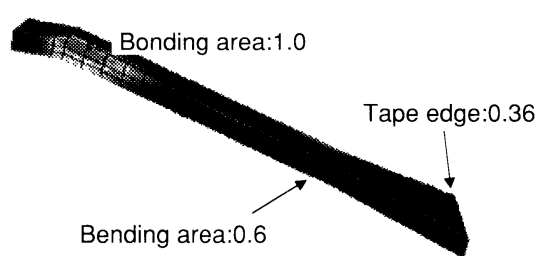

(b) Straight shape

Fig.6 Effect of cross-sectional shape of inner lead on equivalent plastic strain 
に発生するひずみを低減できる。

\section{3 エラストマー厚と弾性率の影響}

樹脂封止部のリードに発生するひずみは，エラストマー の変形によって発生するため, 変形量を決定するエラスト マーの厚さや弾性率の影響を把握しておく必要がある。そ こで, エラストマー厚とエラストマーの弾性率がリードの 相当塑性ひずみに及ぼす影響を検討した。

Fig. 7 に，リード各部に発生する相当塑性ひずみのエラ ストマー厚依存性を示す。解析したリードは，Fig. 6 (a)に 示したようなテープ根元から屈曲部まで水平部を設けた $\mathrm{S}$ 字形状とし，テープ根元部のリード幅を $64 \mu \mathrm{m}$, 根元から $100 \mu \mathrm{m}$ 離れた位置まで幅方向にテーパ部を有する構造とし た。エラストマーが厚くなるとリード各部に発生するひず みの大小関係が逆転し，最大ひずみの発生個所が，チップ 接合部からテープ根元部へ移行する。本解析では，チップ 接合部とテープ根元間の水平方向距離を一定としてエラス トマー厚のみを変えているため，エラストマーが薄い場合 ほどリード長が短くなり，リード形状が相対的にFig. 6 (b) のようなストレート形状に近づくため，チップ接合部のひ ずみが増加したものと考えられる。一方，エラストマーが 厚くなると, 厚さ方向の変形量増大にともなってテープ根 元部のひずみが増加する。したがって，リードに発生する ひずみを最小にするにはエラストマー厚を 2 曲線の交点で ある約 $100 \mu \mathrm{m}$ とすることが望ましい。しかし，Fig. 6 (a)の ようなリード形状を安定して形成することと，後述するは んだ接続部の信頼性を考慮して，エラストマー厚は $150 \mu \mathrm{m}$ を目安として構造設計を進めることにした。エラストマー が厚くなるとテープ根元部のひずみは大きくなるが，Fig. 5 に示したようにテープ根元部の幅広化を適正にすること でひずみのさらなる低滅が可能なためである。

Fig. 8 は，樹脂封止部のリードに発生する最大ひずみの エラストマーの弾性率依存性を解析した結果である。エラ ストマーなどの樹脂材料では，一般に弾性率と線膨張係数 の間には負の相関がある。本解析では，弾性率を $10 \mathrm{MPa}$ 〜 10GPaの範囲で変化させ, 各弾性率に対応した線膨張係

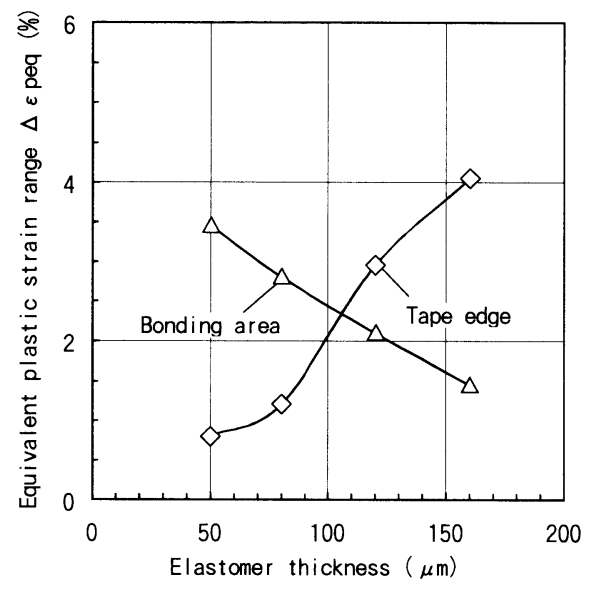

Fig.7 Relationship between equivalent plastic strain range and elastomer thickness

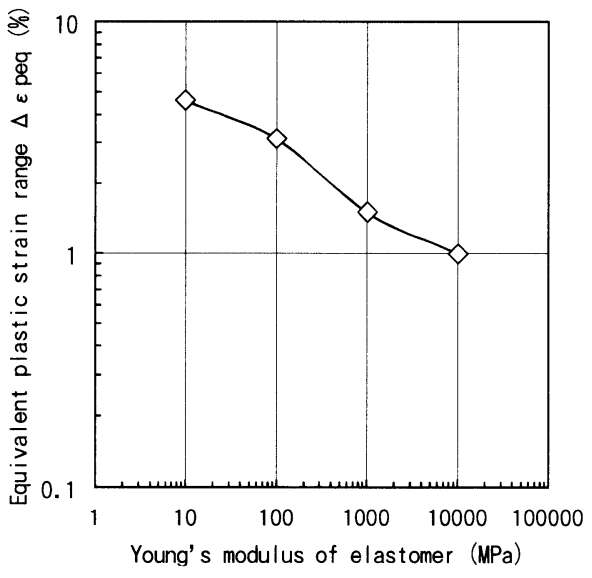

論

Fig.8 Relationship between equivalent plastic strain range and Young's modulus of elastomer

Table 2. Material properties of elastomer

\begin{tabular}{c|c|c|c|c}
\hline & & $\begin{array}{c}\text { Young's } \\
\text { Modulus } \\
(\mathrm{MPa})\end{array}$ & $\begin{array}{c}\text { Poisson's } \\
\text { Ratio }\end{array}$ & $\begin{array}{c}\text { Coefficient } \\
\text { of Thermal } \\
\text { Expansion } \\
\left(\mathrm{ppm} /{ }^{\circ} \mathrm{C}\right)\end{array}$ \\
\hline \multirow{5}{*}{ Elastomer } & $\mathrm{A}$ & 10 & 0.45 & 250 \\
\cline { 2 - 5 } & $\mathrm{B}$ & 100 & 0.45 & 130 \\
\cline { 2 - 5 } & $\mathrm{C}$ & 1000 & 0.45 & 65 \\
\cline { 2 - 5 } & $\mathrm{D}$ & 10000 & 0.45 & 20 \\
\hline
\end{tabular}

数は, 一般的な樹脂材料の弾性率と線膨張係数の関係を考 慮してTable 2 に示した值を使用した。解析したリードの 幅は $42 \mu \mathrm{m}$ 一定とし，Fig. 6 (a)と同様な形状とした。エラ ストマーの厚さは $150 \mu \mathrm{m}$ である。リードに発生する相当塑 性ひずみは，エラストマーの弾性率を $10 \mathrm{MPa}$ か $1000 \mathrm{MPa}$ にすると単調に減少して，約 $1 / 3$ となる。

以上述べてきたように，リードのひずみの主要な決定因 子は，リード根元部分の幅や長手断面形状，およびエラス トマー厚と弾性率であり，これらの適正化によってひずみ 低減が可能であることが明らかとなった。これらの構造因 子の中で, エラストマーの弾性率は, はんだ接続部の信頼 性にも影響するため, リードとはんだ接続部両者の信頼性 をバランス良く確保するためのさらなる構造適正化が不可 欠である。

\section{4. 内部リードの疲労強度}

パッケージの構造設計にあたっては，定量的な信頼度評 価が必要であり，樹脂封止部のリードについても発生ひず みに対するリードの疲労寿命を推定する必要がある。そこ で，内部リードの疲労寿命を評価するために，リードの疲 労試験を行って相当塑性ひずみと寿命の関係を把握するこ とにした。

疲労試験は, 厚さ $25 \mu \mathrm{m}$, 幅 $95 \mu \mathrm{m}$ の短冊状になった電解 銅䈃を, 厚さ $75 \mu \mathrm{m}$ のポリイミドテープに接着したものを 試験片として, Fig. 9 のような片持ち梁状態の両振り曲げ 条件で行った。変位を一定にして繰り返し曲げを加え,リ ードの破壊状態を顕微鏡で観察し, リードが断線するまで 


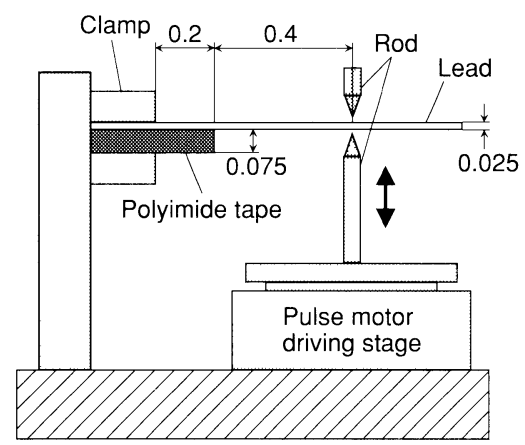

Fig.9 Loading condition of fatigue test

の繰り返し数を寿命と定義した。2 次元平面応力の弾塑性 有限要素法解析によって, 各試験時のリードの最大相当塑 性ひずみ範囲を算出し，疲労曲線を求めた。Fig.10は疲労 試験結果をまとめたりードの疲労寿命曲線である。相当塑 性ひずみと寿命は両対数グラフ上でほぼ一直線上にプロッ トでき，銅䇴リードの $50 \%$ 断線発生の寿命曲線として次式 を得た。

$\mathrm{Nf}=16700 \Delta \varepsilon \mathrm{peq}^{-2.1}$

ここで，Nfは断線寿命， $\Delta \varepsilon$ peqは相当塑性ひずみ範囲で あり，単位は\%である。

(1)式から，例えば50\%断線寿命 1000回を達成するため には，樹脂封止部のリードに発生する相当塑性ひずみを 3.8\%以下にする必要がある。リードのひずみをこの值以 下にするためには，リード形状の適正化とともに，Fig. 8 に示したようにエラストマー弾性率を100MPa以上にする ことが必要である。したがって，リードの信頼性向上には シリコーン系樹脂よりも高弾性の材料選定が不可欠とな

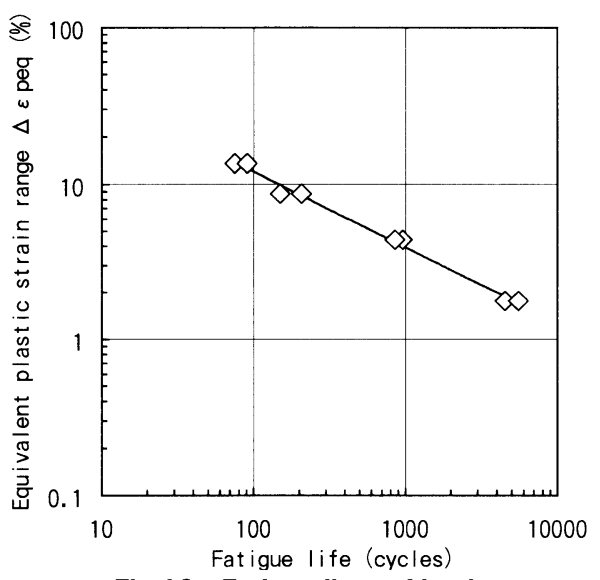

Fig.10 Fatigue lives of lead
る。

今回得られた寿命曲線によって，樹脂封止部のリード寿 命の定量的予測が可能となったので，次章で具体的な構造 最適化を進める。

\section{5. 応力緩和層内包タイプファインピッチBGAの最適 構造設計}

\section{1 はんだ接続部と内部リードの信頼性向上設計}

リードのひずみを低減し信頼性を向上するためには，上 述したようにテープ根元部の幅広化や長手断面形状のS字 化，あるいはエラストマー厚の適正化といった構造面での 対策と，エラストマーの高弾性化が有効である。特にエラ ストマーの高弾性化によるひずみ低減は，製造プロセスで のエラストマー厚やリード形状のばらつきを考慮すると， 信頼性マージン確保のために不可欠であると考えられる。 しかし，エラストマーの高弾性化ははんだ接続部に発生す るひずみを増加させるため，信頼性低下の原因となる。そ こで，リードとはんだ接続部両者の信頼性をバランス良く 確保するエラストマー弾性率を明確にするため，はんだ接 続部寿命のエラストマー弾性率依存性を評価した。

解析したパッケージ構造は，Fig. 2 と同じであり，エラ ストマー厚は $150 \mu \mathrm{m}$ とした。パッケージの全体形状とはん だバンプの構造をFig.11に示す。実装基板の板厚方向の変 形を拘束して両面実装を模擬し，温度範囲 $-55^{\circ} \mathrm{C} \sim 125^{\circ} \mathrm{C}$ で解析した。最大ひずみが発生すると予想されるパッケー ジコーナーのバンプのみFig.11(b)に示すような詳細に要素 分割を行った球状バンプとし，残りのバンプは角柱でモデ ル化した。解析ソフトはADINAを使用し，はんだバンプ のみを弾塑性体とした 3 次元弹塑性解析を行った。また, 解析で求めた相当塑性ひずみ範囲から破壞寿命の算出に は，はんだボール接合試験片のせん断度労試験によって求 めた疲労強度デー夕沼を使用した。

Fig.12は，相当塑性ひずみ範囲から算出したリードとは んだ接続部の $50 \%$ 断線寿命のエラストマー弾性率依存性を まとめた結果である。エラストマー弾性率の増加に伴いは んだ接続部の寿命は減少するが,リードの寿命は増加する。 したがって，はんだ接続部とリード両者の信頼性を考慮し て寿命を最も長くするためには，寿命曲線の交点近傍に工 ラストマー弾性率を設定するのが有効であり，Fig.12では

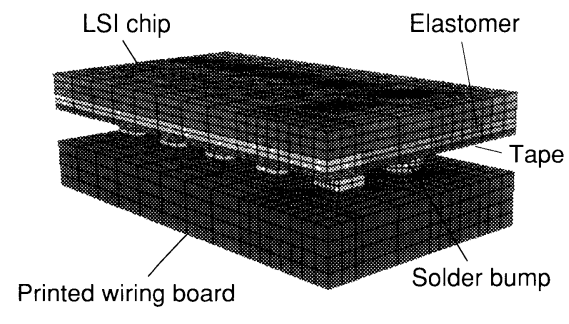

(a) Package
LSI chip

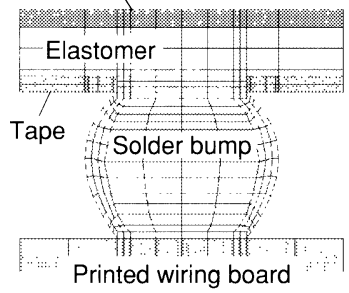

(b) Solder bump joint

Fig.11 FEM model for estimating strain in solder bump joint 


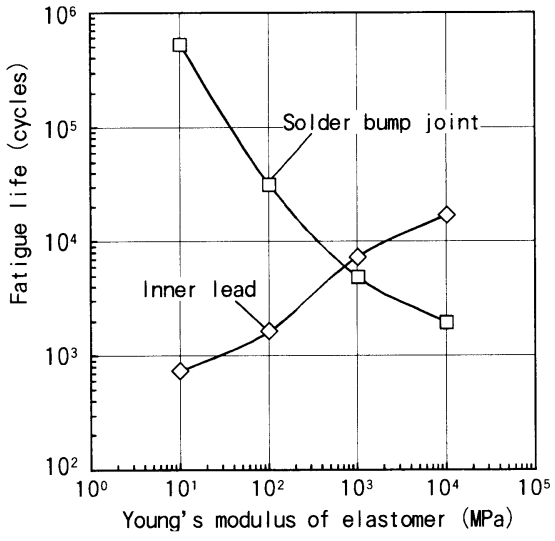

Fig.12 Effect of Young's modulus of elastomer on fatigue lives of inner lead and solder bump joint

Table 3. Properties of elastomer of developed CSP

\begin{tabular}{c|c}
\hline Young's Modulus at $25^{\circ} \mathrm{C}(\mathrm{MPa})$ & 550 \\
\hline $\begin{array}{c}\text { Coefficient of Thermal Expansion } \\
\left(\mathrm{ppm} /{ }^{\circ} \mathrm{C}\right)\end{array}$ & 86 \\
\hline $\begin{array}{c}\text { Glass Transition Temperature } \\
\left({ }^{\circ} \mathrm{C}\right)\end{array}$ & 180 \\
\hline
\end{tabular}

約1000MPaが適正値となる。

以上述べた検討結果に基づき，エラストマー材料として フッ素系多孔質材のコア層とその両側にエポキシ系接着剤 層を設けた構成の材料を採用した 10.111。このエラストマー 材料の主な物性はTable 3 に示すと抢りであり, 弾性率は 室温において約550MPaである。

\section{2 封止樹脂の物性值を考慮した構造設計}

前節までの構造解析では，リードを覆う封止樹脂にシリ コーン系樹脂を想定した低弾性材料を用いていたが，エラ ストマー樹脂の高弾性化に対応して, 封止樹脂物性も適正 化を図る必要がある。また, リード自体の変形がリードに 発生するひずみ堌加の主原因であるため, リードを覆う封 止樹脂も高弾性にすることでリードのひずみが低減できる と考えられる。そこで，封止樹脂に高弾性材料を使用した 場合のリード寿命を評価した。

解析したパッケージはFig. 2 と同様である。本解析では, 比較的詳細に要素分割を行ったリードを加えた 3 次元のパ ッケージ全体モデルから直接リードのひずみを求めること にした。解析した温度範囲は $-55^{\circ} \mathrm{C} \sim 150^{\circ} \mathrm{C}$ の $205^{\circ} \mathrm{C}$ である。 解析したリードのテープ根元部の幅は $130 \mu \mathrm{m}$ として根元か ら幅が連続的に減少するテーパ部を設け，チップ接合部の 近傍に最小幅 $38 \mu \mathrm{m}$ の部分を形成した。エラストマーは Table 3 に示したフッ素系多孔質材をコア層とする材料と し，厚さは $150 \mu \mathrm{m}$ とした。封止樹脂にはエポキシ系のポッ ティング材料を想定して, Table 4 に示す 6 種類の材料を それぞれ用いて解析した。なお， Table 4 に示した各封止 材料は, 解析温度範囲内の $100^{\circ} \mathrm{C}$ にガラス転移温度が存在 するため，ガラス転移温度上下で線膨張係数 $\alpha 1 ， \alpha 2$ が それぞれ定義されている。しかし本解析では解析を容易に するため，線膨張係数にはガラス転移温度と $\alpha 1 ， \alpha 2$ の
Table 4. Material properties of encapsulant

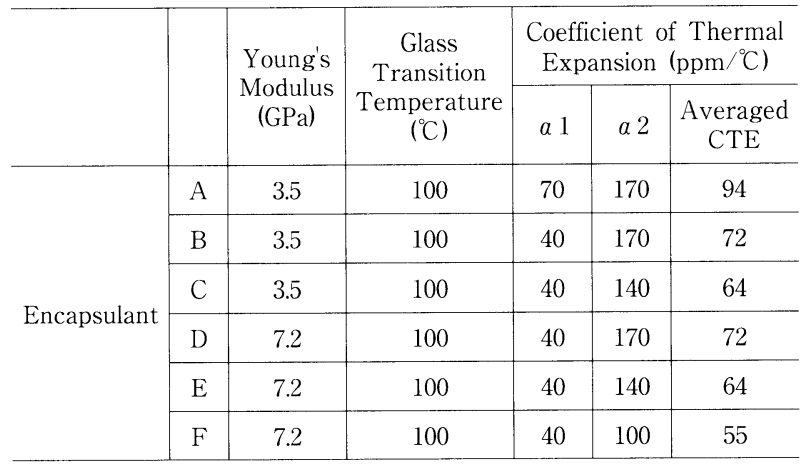

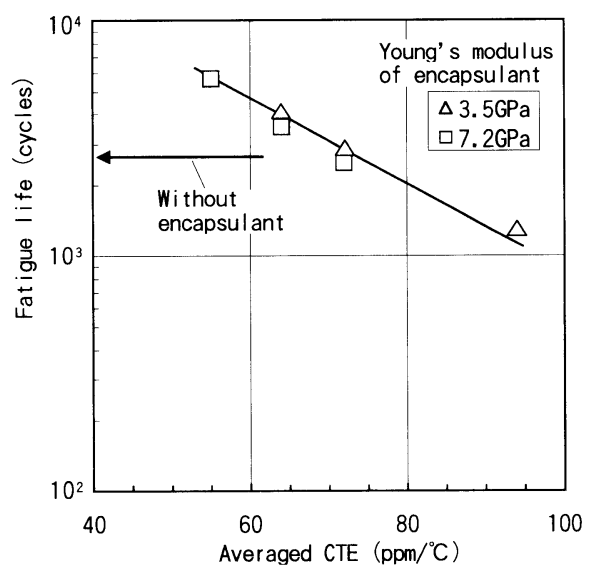

Fig.13 Effect of encapsulant CTE on fatigue lives of inner lead

值を考慮した解析温度範囲内での平均的な值を用いた。実 際に使用した各材料の平均の線膨張係数も表中に併記した。

Fig.13に，リードの50\%断線寿命に対する封止材の平均 線膨張係数依存性を示す。図中の矢印で示した值は, 低弾 性封止材使用時の寿命推定のため, 封止材を除去したモデ ルで解析した結果である。数GPa以上の高弾性材料で封止 した場合，最大ひずみはリード幅が狭くなっているチップ 接合部に発生する。一方，封止材を除去した場合はテープ の根元部が最大となっており, Fig. 7 に示したエラストマ 一が厚い場合の最大ひずみ発生個所と一致した。高弾性材 料で封止したリードの寿命は, 封止材の平均線膨張係数が 小さくなると増加し, 封止材弾性率を 2 倍程度変えても寿 命に変化は認められない。封止材の平均線膨張係数が大き くなると低弾性（数十MPa程度）封止材構造より寿命が 短くなる場合があり, 低弾性封止材と同等以上の信頼性を 確保するためには, 平均の線膨張係数を $70 \mathrm{ppm} /{ }^{\circ} \mathrm{C}$ 以下に する必要があることが明らかとなった。以上の結果から， 高弾性材料で封止した場合は, 封止樹脂自体の熱変形によ ってリードのひずみが決定され，封止材の平均の線膨張係 数が重要な設計因子となることが明らかとなった。寿命を 向上するための平均の線膨張係数低減には, 線膨張係数 $\alpha$ $1 ， \alpha 2$ の低減とガラス転移温度の高温化が有効であり, Fig.13で明らかとなった平均の線膨張倸数 $70 \mathrm{ppm} /{ }^{\circ} \mathrm{C}$ 以下 を目安として材料を選定した。

\section{3 高信頼ファインピッチBGAの開発}

以上述べた検討結果に基づいてパッケージ材料と構造を 
Table 5. Properties of encapsulant of developed CSP

\begin{tabular}{c|c}
\hline Young's Modulus at $25^{\circ} \mathrm{C}(\mathrm{MPa})$ & 8500 \\
\hline Coefficient of Thermal Expansion a & 38 \\
\hline Gpm $\left./{ }^{\circ} \mathrm{C}\right)$ & 102 \\
\hline
\end{tabular}

適正化した。エラストマー樹脂には, Table 3 に示したフ ッ素系多孔質材をコア層とする材料を採用した。封止樹脂 には，Table 5 に示す物性を有するエポキシ系のポッティ ング樹脂を採用した101.11)。この封止樹脂の平均の線膨張係 数（温度範囲 $150^{\circ} \mathrm{C} \sim-55^{\circ} \mathrm{C}$ ） は, 約 $60 \mathrm{ppm} /{ }^{\circ} \mathrm{C}$ であり, 前節で目安とした值 $\left(70 \mathrm{ppm} /{ }^{\circ} \mathrm{C}\right)$ 以下となっている。エ ラストマーの厚さは約 $150 \mu \mathrm{m}$ とし，パッケージサイズやは んだバンプ構造および製造プロセスに応じて最適化を図る ことが必要である。またリードにはAuめっきを施した $\mathrm{Cu}$ 採用し，樹脂封止部のリード形状はテープ根元部分 を幅広とし，根元部分からチップ接合部に向かって連続的 に幅が減少するテーパ部を有する構造とした。

これらの材料構成で試作した周辺パッドタイプの 48 ピン ファインピッチBGA（パッケージサイズ $5.03 \times 8.24 \mathrm{~mm}$ ) は，基板実装状態の温度サイクル試験 $\left(-55^{\circ} \mathrm{C} / 125^{\circ} \mathrm{C}\right)$ に扔いて，1500回で不良が発生して扔らず $(0 / 30 \text { 個 })^{100}$, 高い信頼性が得られることを確認した。

今回開発した応力緩和層を内包したファインピッチ BGAタイプのCSPは，温度サイクル性だけでなく耐湿性 や耐リフロー性にも優れて抢り，次世代の高速DRAM (Dynamic Random Access Memory)用のCSPとして高い 信頼性を有していると考えている。

\section{6. 結 言}

応力緩和層内包夕イプの高信頼ファインピッチBGAの 開発を目的として，封止樹脂部のリードとはんだ接続部の ひずみに及ぼすパッケージ構造因子を解析的に検討し，信 頼性を向上するためのパッケージ構造仕様を明らかにし た。主な結論を以下に示す。

1）樹脂封止部のリードに発生するひずみは，テープ根 元部の幅広化, 長手断面のS字形状化によってリード の複数個所に分散することで低減できる。

2) エラストマー厚によってリードの最大ひずみ発生個 所が変化し，ひずみが最小となるエラストマー厚が存 在する。

3）エラストマー弾性率の最適化によって，はんだ接続 部とリード両者の信頼性を確保し，パッケージの寿命 を長くすることができる。

4) 平均的な線膨張係数を $70 \mathrm{ppm} /{ }^{\circ} \mathrm{C}$ 以下とした数 $\mathrm{GPa}$ の弾性率を有する材料でリードを封止することによ り，リードの信頼性を向上できる。

5）以上の構造設計の結果，基板実装状態で $-55 / 125^{\circ} \mathrm{C}$ の温度サイクル寿命1500回以上を達成するファインピ
ッチBGA構造を開発した。

\section{謝 辞}

本研究を進めるにあたり疲労試験サンプルの提供ととも に有益なご討論をいただいた，日立電線電線工場の村上元 氏，御田護氏，岡部則夫氏に心から謝意を表する。

(2000.10.10-受理２001.1.24-再受理）

\section{文献}

1) 朝倉博史：“構造を改良したCSPで接続信頼性をクリア”, 日経マイクロデバイス 2 月号, pp.48-55, 1988

2) T.DiStefano：“多ピン・高速対応の主役の座を目指す新型 CSP技術の全貌”，日経マイクロデバイス10月号，pp.92-98， 1996

3) 安生一郎, 春田 亮, 橋爪孝則, 佐伯準一, 永井 晃, 北 野誠：“テープBGAタイプCSPの開発”, 信学技報, CPM96-121, ICD96-160, 1996-12

4) 安生一郎, 春田 亮: “日立製作所のCSP開発・実装技術と 今後の展開”，表面実装技術，Vol.5, pp.35-38， 1995

5) T.DiStefano: "The Micro-BGA as a Chip Size Package", in Proc. Technical Program, NEPCON WEST '95, pp.327-333, 1995

6) R.Mahidhara, V.Solberg, T.DiStefano, and S.Greathouse : "Solder Joint Integrity in Tessera's $\mu$ BGA Package", Design and Reliability of Solder and Solder Interconnections, TMS, Warrendale, PA, pp.403-412, 1997

7) P.Lall, and K.Banerji : “Assembly-level Reliability Characterization of Chip-Scale Packages", Proc. of 48th ECTC, pp.482-494, 1998

8) 西山芳朗: “ $\mu \mathrm{BGA}$ の構造と実装信頼性”, 電子材料 5 月号 別冊, pp.80-85, 1999

9) 西山芳朗，他：“ $\mu \mathrm{BGA}$ の信頼性について”，第12回回路実 装学術講演大会講演論文集，pp.153-154，1998

10) Y.Akiyama, A.Nishimura, I.Anjoh, and A.Nagai : "Chip Scale Packaging for Memory Devices", Proc. of 48th ECTC, pp.477-481, 1998

11) 安生一郎, 村上 元：“低コスト化の実現に向け材料開発と 生産性向上を実現”，日経マイクロデバイス 4 月号，pp.7678, 1999

12) 矢口昭弘, 他：“高信頼ファインピッチBGAの構造設計技 術”, 第 9 回マイクロエレクトロニクスシンポジウム論文集, pp.161-164, 1999

13）熊沢鉄雄，他：“はんだボール接合部の寿命評価”，第11回 回路実装学術講演大会講演論文集，pp.149-150，1997

14）北野 誠, 河合末男, 清水一男: “面付実装形ICパッヶージ はんだ接合部の熱疲労強度評価”, 日本機械学会論文集， 54-505, A, pp.1709-1715, 1988 